\title{
The organisational and geographic diversity and innovation potential of EU-funded research networks
}

\author{
Daniel Nepelski ${ }^{1} \cdot$ Vincent Van Roy $^{1} \cdot$ Annarosa Pesole $^{1}$
}

Published online: 14 September 2018

(c) The Author(s) 2018

\begin{abstract}
Public funding of research improves the systemic conditions of entrepreneurial ecosystems. It provides early-stage financing to technologies that form the basis for new products and services. In addition to financial support, instruments as the EC Framework Programmes (FP) facilitate the creation of research networks. By bringing together organisations of various types and geographic origins and increasing the diversity of their interactions, the instrument seeks to accelerate a discovery process in which organisations attempt to bring desired innovations to the market and society. In this paper, we examine the impact of organisational and geographic diversity of partnerships in EU-funded research networks on the commercial potential of their innovations. We explore a sample of 603 collaborative research projects supported by European FPs. We use data from the Innovation Radar, a unique survey database developed by DG CONNECT to assess the innovation outcomes of FP projects in ICT. We show that innovations developed by research networks with a higher organisational diversity have more commercial potential. This finding supports the idea that policies improving systemic conditions of entrepreneurship ecosystems through the creation of institutionally diverse research networks can have beneficial effects on the commercialisation potential of innovations developed in FP projects. In contrast, research networks with a wider range of internationally dispersed research partners are likely to have less innovation potential. This may suggest the existence of coordination and communication difficulties in FP projects where geographic diversity is greater.
\end{abstract}

Keywords Research networks · Innovation policy $\cdot$ Framework programme $\cdot$ Diversity

JEL Classification L52 $\cdot \mathrm{L} 53 \cdot \mathrm{O} 31 \cdot \mathrm{O} 32 \cdot \mathrm{O} 25$

Disclaimer: The views expressed are purely those of the authors and may not in any circumstances be regarded as stating an official position of the European Commission.

Vincent Van Roy

vincent.van-roy@ec.europa.eu

1 Joint Research Centre (JRC), European Commission, Calle del Inca Garcilaso 3, 41092 Seville, Spain 


\section{Introduction}

Framework and systemic conditions constitute key elements of entrepreneurial ecosystems (Stam and Spigel 2016). Framework conditions include the institutions, physical conditions or demand for new value, and systemic conditions contain, among others, networks, leadership, finance, talent or new knowledge. Whereas the role of the public sector in creating entrepreneurship-friendly framework conditions is relatively well understood (Fuerlinger et al. 2015; Van Roy and Nepelski 2016, 2017), its impact on systemic conditions is less clear. The most obvious is the function of public funding. In Europe, for example, various instruments of funding exist to improve the process of knowledge creation and innovation at all stages of technology development and commercialisation (Gampfer et al. 2016). Many young companies benefit from early-stage financing and state-sponsored technologies, which often form the basis for their new products and services (Mazzucato 2013). Through a high-level investment in risky and new technology projects, the public sector helps to create the markets of the future. In this context, the European Commission's (EC) Framework Programmes (FPs) have a long history of public support of the innovation and entrepreneurship ecosystems. But the objectives of the FPs go far beyond providing funding to technology development. They also aim at improving the systemic conditions of the innovation and entrepreneurship ecosystems by facilitating the creation of research networks between different organisations. In creating and exploiting diversified research networks, FPs are expected to trigger technological and economic transformation (Audretsch and Link 2016; EC 2016; Leyden 2016; Link 2016). One of the underlying assumptions behind the design of the FPs is that network diversity is a positive factor. It is expected to increase the level of innovation and to facilitate discovery of cross-border applications and solutions.

In this context, an important question for policy makers is: to what extent is a greater degree of organisational and geographic diversity in EU-funded collaborative research networks beneficial to their economic outcomes. In this paper, we explore the innovation potential of EU-funded collaborative research networks and investigate how this potential is related to the degree of organisational and geographic diversity of organisations involved in the development of innovations. We analysed a sample of 603 collaborative research networks from various EU-funded FPs.

An extensive body of literature has explored the benefits and drawbacks of organisational and geographic diversity in collaborative research networks and strategic alliances (e.g. Belderbos et al. 2004; Laursen and Salter 2006; Duysters and Lokshin 2011). Overall, a greater diversity in the type of research partners opens up greater opportunities for interorganisational learning (Luukkonen 1998, 2000), provides access to diverse competencies (Kogut 1988; Hagedoorn 1993; Caloghirou et al. 2001), leads to a greater variety of ideas and creativity and contributes to more effective problem solving. At the same time, institutionally more diverse research consortia face difficulties due to differences in institutional culture across research partners (Goerzen and Beamish 2005; Pandza et al. 2011). In addition, managerial problems may arise when the various organisations engaged in collaborative projects attempt to reconcile their different objectives and time-frames (Harryson et al. 2008). Finally, a greater degree of geographic diversity in collaborative research networks is generally associated with greater coordination and transaction costs.

This paper contributes in various ways to the literature on this topic. First, it focuses on the collective performance of research projects. So far, impact assessment studies of EUfunded collaborative research projects have mainly explored how participating in these projects has affected aspects of firms' economic performance, such as profitability or employment change (Bayona-Sáez and García-Marco 2010; Barajas et al. 2012; Aguiar and 
Gagnepain 2017). Second, it exploits a unique survey database developed by DG CONNECT that provides valuable information about both the innovators participating in EUfunded collaborative research projects with an ICT theme and the innovations developed by them (De Prato et al. 2015; Nepelski and Piroli 2018). This allows us to approach the notion of innovation from a holistic perspective in which innovation potential is not merely measured by innovation output, i.e. filed patent applications. In this paper, the innovation potential of EU-funded research projects is measured as a composite indicator which captures various determining dimensions of the innovation and technology development process, including the levels of innovation readiness, management and market potential.

The remainder of this article is structured as follows. Section 2 briefly reviews the relevant existing literature on the benefits and drawbacks of organisational and geographic diversity in collaborative research settings. It presents the most recent literature on impact assessments of Framework Programmes. ${ }^{1}$ This is followed by a description of the methodology and data sources used to measure innovation potential and diversity in EU-funded research networks. Descriptive statistics are given in Sect. 4 and the empirical results in Sect. 5. Finally Sect. 6 offers some concluding remarks and recommendations for future research.

\section{Previous literature}

Since 1984, the European Commission has launched several Framework Programmes (FP) to support cooperative R\&D within the European Union. The main objectives of these programmes are to sustain and enhance the international competitiveness of European industry and to increase the wellbeing of citizens (Caloghirou et al. 2004). FPs allocate public funding specifically to research consortia which involve partners from various countries and institutional settings to carry out collaborative research projects. Usually these consortia are made up of firms (SMEs and large firms), universities, public research centres and government institutions (Barajas et al. 2012).

Public interventions of this kind are traditionally seen as mechanisms to overcome market failures. Market failures can arise when firms cannot preclude dissemination of knowledge to competitors and hence are prevented from fully appropriating the returns of their R\&D efforts. This may lead to lower investment in innovation activity than is socially desirable (Nelson 1959; Arrow 1962). The FPs incorporate two types of public policies that are commonly used to reduce this market failure. First, FP projects must be co-funded through grants from the European Commission and private funds from consortia partners. The use of direct financial support for R\&D by means of grants incentivises firms to pursue socially valuable R\&D projects that would not be conducted otherwise. Second, FPs are designed to encourage close and strategic R\&D collaboration among different partners. This collaboration makes it possible to partially internalise knowledge leaks and thus increases the appropriability of returns within the research consortia.

In addition to the intervention to solve market failures, FPs also play a more active and mission-oriented role in creating and encouraging new market opportunities and in developing emerging sectors (Audretsch and Link 2016; Leyden 2016; Mazzucato 2016). In this

\footnotetext{
1 We acknowledge that the impact of organisational and geographic diversity on innovation performance has received ample attention in the scientific literature (e.g. Belderbos et al. 2004; Laursen and Salter 2006; Duysters and Lokshin 2011). However, we restrict the literature review to the handful of publications that provide evidence for publicly-funded research projects to target more closely the main subject of this paper.
} 
respect, FPs serve as policy tools that shape the directionality of technology and economic transformations. By fostering the creation and consolidation of institutionally and internationally diverse research networks within the European area, FPs facilitate discovery of cross-border applications and solutions. One of the objectives of FPs is to tackle largescale societal challenges and complex research projects that require relevant knowledge more likely to be found in networks of organisations. Thus, publically-funded research programmes such as the FPs have a threefold impact on systemic conditions of entrepreneurship ecosystems. First, they provide finance for high-risk projects with uncertain commercial potential. Second, they direct and accelerate the process of novel, market-creating technologies. Third, they increase the level of connectedness between organisations of various types, background and roles in the economy and society.

In line with these considerations, the economic and societal impacts of research networks and in particular FPs are manifold. First, FPs have been particularly successful in incorporating smaller and peripheral communities in the wider European network, strengthening the research integration and cohesion in Europe (Protogerou et al. 2013). Second, research networks are effective for both the creation and diffusion of knowledge and technologies, which can further spur regional or national wealth and competitiveness (Lehmann and Menter 2016). Analysing a panel of countries that participated in FP over the period 1994-2005, Di Cagno et al. (2014) find that participation in EU-funded research projects is an important channel of knowledge transfer. New knowledge produced within research networks can for instance spill over to the local market by means of labour mobility, patent licensing and research contacts. Finally, besides the beneficial societal impact of the creation of new technologies and spillover effects, research networks can lead to the creation of new firms that emerge during the collaborative efforts.

To increase the economic and societal impact of research networks, a better understanding of the formation of the networks in terms of the organisational and geographic diversity of participating entities and their economic outcome is of great importance. The impact of both organisational and geographic diversity in collaborative research networks has been extensively explored. As organisations and nations provide institutional and national boundaries for groups of people with different cultural backgrounds, the literature on organisational and geographic diversity relate extensively to the literature on cultural diversity. To a large extent the variety of cultural backgrounds of individuals shapes the diversity in terms of education, know-how, experiences and objectives in organisations and defines the advantages and drawbacks of collaborative endeavours in a setting with multiple organisations and countries. A large strand of literature has analysed the effect of cultural diversity on individual, group and organisational outcomes (Cox 1993). The most recurrent arguments highlighting the positive advantages of cultural diversity are the access to a broad base of talent thriving creativity, a better problem-solving capacity and a better ability in dealing with complex issues (Cox and Blake 1991; Ely and Thomas 2001). Common drawbacks of a large cultural diversity are increased costs in time and financial resources due to conflicts and communication issues (Brett et al. 2006; Stahl et al. 2010).

Performing an in-depth study by means of interviews of a small EU project funded by the Framework Programme, Ahonen and Tienari (2009) highlight the importance of diversity management in an institutional diversified setting with transnational organisations. The authors mainly analyse power relations and the role of knowledge. In line with their discussion and the literature on cultural diversity, we provide below a detailed overview of the advantages and disadvantages of organisational and geographic diversity in research networks. 


\subsection{Organisational diversity}

Given the increasing complexity of innovations and the limited resources and competencies of individual organisations, the number of research collaborations has grown rapidly during the last few decades (Hagedoorn and Kranenburg 2003; Faems et al. 2005; Pavitt 2005; Aristei et al. 2016). The rapid development of research carried out in collaboration by different types of organisations is driven by several advantages.

Working together with other organisations gives research partners access to knowledge and complementary assets that they do not possess in-house (Teece 1986; Hagedoorn 1993; Powell et al. 1996). Conducting research and development with external partners allows partners to create and mobilize more resources than would be possible through their individual efforts (Das and Teng 2000). Collaborative research reduces the risks associated with the R\&D-intensive projects, but requires enough internal R\&D knowledge on the part of the research partners to understand, assimilate and exploit the accessed or acquired external technology (Cohen and Levinthal 1990). Overall, research collaborations with different types of partners serve as conduits for information and learning and are of strategic importance in the diffusion of tacit and codified knowledge (Eisenhardt and Schoonhoven 1996; Doz and Hamel 1997; Ahuja 2000). Hence, research collaborations are seen as effective means of getting information about new practices and they serve as a radar function to screen promising new technologies (Freeman 1991; Powell and Brantley 1992; Ahuja 2000; Ahuja and Lampert 2001).

Luukkonen (1998, 2000) investigated the benefits of participating in Framework Programmes. He reported that improvement of skills, expansion of research lines and access to larger networks of contacts and capabilities were among the most frequently mentioned advantages of European Framework Programmes.

At the same time, greater heterogeneity of organisation types in research collaborations can be a hindrance to the economic performance of research networks. The potential benefits of organisational diversity may be consumed by greater communication and information exchange problems, differences in institutional culture (Zucker 1986; Hennart and Zeng 2002), incompatible reward systems (e.g. publications versus commercial products and services), managerial issues and barriers to trust (Goerzen and Beamish 2005; Pandza et al. 2011). Analysing research collaborations in FP projects, Archibugi and Coco (2004) show that firms may be reluctant to engage in collaborative partnerships for competitive reasons. Similarly, Röller et al. (2007) show that large firms are less willing to share their economic knowledge with smaller rivals and prefer to collaborate with other large firms in order to maximise the internalisation of spillovers.

According to Harryson et al. (2008), another fundamental issue in interorganisational collaboration arises from having to reconcile different objectives, time-frames and from finding optimal network structures for innovation. For SMEs, alliances with external partners are often driven by a lack of internal financial resources or technological and managerial competences (Lerner and Merges 1998). Accordingly, SMEs have a strong strategic alignment with FP projects and explicit goals related to innovation outputs such as developing a prototype, a patentable technology, or a complementary technology that will directly enhance their competitiveness (Polt et al. 2008). They focus on projects with an applied orientation and engage only in cooperative agreements that are likely to yield tangible benefits and guarantee their immediate survival and growth (Miles et al. 1999; Baum et al. 2000).

Large firms appeared much less inclined to commercialise right out of the project than SMEs which are highly committed to commercialisation. Because of the more marginal 
role of FP projects, larger companies reported weaker strategic alignment and less explicit goals. For them, participation in research collaborations means technology watch, acquisition of new knowledge and building partnerships (Hernán et al. 2003).

Universities and public research centres, on the other hand, participate in research collaborations in order to acquire complementary resources that allow them to advance research (Caloghirou et al. 2001; Polt et al. 2008). Based on their scientific capabilities, universities engage in research collaborations for their research contents (Carayol 2003). The main criterion for collaboration is that this content feeds a university's own research agenda. Commercialisation is not the main objective, but rather the building up of new knowledge and technology and the investigation of new research areas.

Overall, industry players tend to engage in research collaborations from a knowledge exploitation strategy which is characterised by a short- and medium-term horizon. Public research institutions, on the other hand, follow a knowledge exploration strategy which tends to have a long-term perspective (Hansen 1999). A wider diversity of organisation types in FP projects provides a variety of roles, competences and expectations through the different phases of the research projects. Hence, collaborations between industry and public institutions may create beneficial complementary effects, but they can at the same time be potential sources of conflict (Pandza et al. 2011).

\subsection{Geographic diversity and geographical proximity}

A great international heterogeneity of partners in a research collaboration implies advantages but also challenges in collaborating with partners located in different countries. The literature highlights the benefits of geographic diversity in gaining access to highly sophisticated, specialised and tacit knowledge from various local sources (Meyer-Krahmer and Reger 1999; Lavie and Miller 2008). Diversity of national backgrounds extends the scope of accessible knowledge bases and provides access to network resources that may spur innovation (Gulati 1999).

However, greater geographic diversity entails higher coordination and transaction costs (Hagedoorn et al. 2000; Caloghirou et al. 2003; Caloghirou et al. 2004; Goerzen and Beamish 2005). Research collaborations characterised by large international heterogeneity are much more complex and difficult to manage. Difficulties in assimilating and coordinating operations across national borders are driven by a lack of face-to-face communications, language barriers and higher costs of information transfer. In addition, when research collaboration involves a wide diversity of internationally dispersed research partners, there is greater difficulty in specifying intellectual property rights, legally enforcing intellectual property, and monitoring partner activities (Pisano 1990; Oxley 1997), which further increases transaction costs. The difficulties that geographic diversity brings along may contribute to the creation of smaller informal clusters within the collaborative research project, which can potentially affect the overall coherence of the project (Goerzen and Beamish 2005).

Besides geographic diversity, the geographical proximity between research partners is recognised as a salient factor, which affects collective innovative endeavours (Audretsch and Feldman 1996; Asheim and Gertler 2005; Boschma 2005). Geographical proximity between research partners is of crucial importance in getting access to tacit and noncodified knowledge from other partners, given that knowledge spillovers are geographically bounded (Jaffe et al. 1993; Anselin et al. 1997). Larger distance may increase communication and coordination difficulties between research partners, and may hamper 
the innovation potential of cooperative projects (Keller 1986; Hoegl and Proserpio 2004; Mora-Valentin et al. 2004).

\subsection{Impact assessment of Framework Programmes}

Despite the long-term tradition of EU-wide public support for R\&D in the form of Framework Programmes, studies evaluating the impact of these interventions on research projects' innovation performance remain relatively scarce. Impact assessment studies of FPs have mainly explored the effect of firms' participation on their economic performance, such as profitability or employment change (Bayona-Sáez and García-Marco 2010; Barajas et al. 2012; Aguiar and Gagnepain 2017). In their analysis of a sample of firms active in FP projects, Aguiar and Gagnepain (2017) showed that participation in the Framework Programme led to a considerable increase in labour productivity though the effect on profit margins remained limited. Similarly, Barajas et al. (2012) found that participating in FPs had a positive impact on Spanish manufacturing firms' technological capabilities, which indirectly translated into an increase of labour productivity. Bayona-Sáez and GarcíaMarco 2010 found that the completion of an FP project had a positive impact on firm performance measured as return over assets.

Notable exceptions are the studies of Nepelski and Piroli (2018) and Schwartz et al. (2012). Nepelski and Piroli (2018) analysed the relationship between the diversity of research partners in FP projects and the potential of their innovations. The authors show that the innovative potential of research output of homogenous partnerships, e.g. between two SMEs or two large companies, is likely to be higher than that of heterogeneous partnerships, e.g. an SME and a large company. In contrast to the current paper, the analysis did not account for all participants of the research networks but explored only the diversity of the three key organisations in delivering innovations in FP projects.

Similarly, Schwartz et al. (2012) explored the factors that drive innovation output from subsidised R\&D cooperation projects in Germany. Using patent applications and publications as measures for the innovation output of the projects, the involvement of large firms in the research consortium is strongly and positively associated with the number of patent applications but not with the number of publications, while university involvement yields the opposite results.

In their exploration of diversity in FP projects, Coad et al. (2017) found negative relationships between the level of organisational diversity, geographic diversity and diversity in terms of members' shares of project cost. These findings suggest that the optimum amount of diversity in one dimension depends on the amount of diversity in other dimensions. Hence, the authors argue that a high level of diversity in one dimension may not necessarily be a liability as long as it can be compensated by sufficient similarity in another dimension. While shedding new light on the interactions across various diversity dimensions in FP projects, Coad et al. (2017) did not explore their effect on research projects' performance.

\section{Data sources and methodology}

\subsection{Innovation potential of research projects}

To investigate the relationship between the organisational and geographic diversity in EUfunded collaborative research projects and their innovation potential, we used information 
from the Innovation Radar. The Innovation Radar (IR) is an EC support initiative that aims to assess the potential of innovations developed within FP research projects and to identify the bottlenecks to their commercialisation (De Prato et al. 2015). Data used to build the innovation potential assessment framework of the Innovation Radar stem from a survey developed by DG CONNECT. The survey was conducted by external experts commissioned by DG CONNECT during periodic reviews of the research projects between October 2014 and January 2016. The Innovation Radar monitors the ICT research actions and the e-infrastructures activity under the seventh Framework Programme 2007-2013 (under cooperation and capacities themes), the policy support actions carried out under the competitiveness and innovation framework policy support programme (CIP ICT PSP) and the ICT-related projects in Horizon 2020 (EC 2014).

The innovation potential assessment framework of the IR is extensively based on the extant literature analysing the antecedents and success factors of new product performances and R\&D projects (Rothwell 1992; Balachandra and Friar 1997; Heslop et al. 2001; Astebro 2004; Evanschitzky et al. 2012). The literature discussing success in innovations and $\mathrm{R} \& \mathrm{D}$ projects is vast and lacks uniformity in the use of project outcome measures (Balachandra and Friar 1997; Cooper and Kleinschmidt 1997). According to Astebro (2004), project commercialisation is one of the most easily operationalized and replicable definition across studies and is in this sense the most objective measure for a project's outcome. In the same vein, the Innovation Radar aims at providing a contingency framework and metrics measuring the project's development towards commercialisation. However, in contrast with this literature the innovation potential indicator does by no means intend to provide a predictive signal of the innovation success, but rather aims to measure the progress that has been undertaken in developing and commercialising an innovation on the market.

A large body of empirical studies has emerged over the past decades aiming at unravelling factors determining the technology development and commercialisation process (for extended surveys see Montoya-Weiss and Calantone 1994; Griffin 1997; Galbraith et al. 2006). Within this empirical literature little convergence exists regarding the number, definition and theoretical grounding for the key factors of effective technology commercialisation (Astebro 2004). Despite the lack of agreement on the specific variables that are used in the empirical analyses, there does, however, seem to be some consensus on the overall classes or groups of these key factors. Based on a meta-analysis of 60 peer-reviewed publications, Balachandra and Friar (1997) proposes four major categories on market, technology, environment, and organisational related characteristics. These categories have been widely recognised and adopted by many scholars in the field of technology commercialisation of R\&D projects (Linton et al. 2002; Astebro 2004). Alternatively, Heslop et al. (2001) use factor analyses to group more than fifty variables related to the technology commercialisation process into four comprehensive dimensions of market readiness, technology readiness, commercial readiness, and management readiness.

Taking stock of these considerations, the Innovation Radar framework is built along the areas discussed in this stream of literature and incorporates them in the following dimensions: market potential, innovation readiness and innovation management (De Coster and Butler 2005; Liao and Witsil 2008). Each of these dimensions is discussed in more detail below.

Innovation readiness A successful launch of innovative products or services begins with the identification of technologies that are ready for commercialisation (Heslop et al. 2001; Galbraith et al. 2006). In this respect, innovation readiness is closely related to the notion of "technology readiness levels" (TRLs) which aim to provide a common understanding of the status and development stage of new technologies (Mankins 2009). 
Originally developed by the NASA in the mid-1970s, the use of TRLs rapidly increased as they enable consistent and uniform assessments of technological maturity across different types of technologies and disciplines. Being discipline-independent, they facilitate more effective communications of the maturity of evolving innovations among diverse organisation types. Factors related to innovation readiness include, among others, the quality of the technology, age, scope, how pioneering it is, and expected time to market. Innovation readiness aims to define the development phase of the innovation, e.g. conceptualization, experimentation or commercialisation. It also takes into account the steps that were taken in order to prepare innovations for commercialisation, e.g. prototyping, demonstration or testing activities or a feasibility study, and to secure the necessary technological resources, e.g. skills, to bring the innovation to the market. In addition, this criterion takes into account the development stage of an innovation and the time to its potential commercialisation.

Innovation management This criterion addresses the issue of the project consortium and its commitment to bringing an innovation to the market. This is often seen as the most important success indicator of a technology venture (Meseri and Maital 2001; Kirchberger and Pohl 2016). In broad terms, it is related to the assessment and management of risks associated with innovation commercialisation. It involves measures such as securing resources, organizing the process and setting milestones for technology transfer. This requires commitment from the top management (Nevens 1990; Davenport et al. 1998). Interactions with external actors, e.g. potential customers or users, also increase the chances of successful commercialisation of technologies (Gerard et al. 2002). Thus, the concept of innovation management aims to capture how far the project's development and/ or management team are able to execute the necessary steps to transform an innovative technology or research results into a marketable product and, finally, to prepare its commercialisation. These steps may include, for example, clarifying ownership and IPR issues, preparing a business plan or market study, securing capital investment from public and/or private sources, or engaging end-users in the project.

Market potential A commercially viable innovation must demonstrate economic benefit. The greater the benefit, the more desirable and marketable an innovation is. At the same time, the innovation commercialisation process involves acquiring ideas about existing or potential market needs and looking for solutions to satisfy them (Mitchell and Singh 1996). The market potential criterion relates to the demand and supply side of an innovation. Regarding the demand side, it concerns the prospective size of the market for a product and the chances of its successful commercialisation. It aims to assess how the product satisfies a market sector and to indicate that there is a potential customer base. Market size and dynamics are among the most relevant factors behind a successful innovation commercialisation (Meseri and Maital 2001). With respect to the supply side, it aims to assess whether there are potential barriers, e.g. regulatory frameworks or existing IPR issues, which could weaken the commercial exploitation of an innovation. In the current undertaking, the focus is placed on the supply side. This is mostly because information on markets for individual innovations is not available.

In order to observe and measure the above-specified criteria, each of them was matched with relevant questions in the Innovation Radar questionnaire. The outcome of the matching process is presented in more detail in prior studies on the IR (De Prato et al. 2015; Pesole and Nepelski 2016). Composite sub-indicators for each assessment criterion were created, i.e. Innovation Readiness Indicator (IRI), Innovation Management Indicator (IMI), and Market Potential Indicator (MPI). In the second step, the Innovation Potential Indicator 
(IPI) was constructed. IPI is an arithmetic composite indicator which aggregates the values of the three earlier sub-indicators. ${ }^{2}$

As mentioned above, the conceptual framework of the Innovation Radar builds on the extant literature on success factors of innovations (see Evanschitzky et al. 2012; Kirchberger and Pohl 2016 for recent surveys). Evanschitzky et al. (2012) provide a meta-analysis of papers published between 1999 and 2011 to assess the effects of factors predicting success of new product innovations and compares the magnitude of these effects found in a previous meta-analysis study of Henard and Szymanski (2001). Both meta-analysis studies show large divergences in the magnitude of success factors of new product innovations. Due to a lack of convergence about the magnitude of success factors in the previous literature, we follow a conservative approach and opt to equally weight the sub-indicators of the Innovation Potential Indicator. With this approach we follow the perspective of scholars claiming that successful development and commercialisation of a new technology is a matter of competence in all factors and of balance and coordination between them and not doing one or two things brilliantly well (Cooper and Kleinschmidt 1988; Rothwell 1992; Conceição et al. 2012).

Hence, equal weighting is applied to construct the Innovation Potential Indicator as follows:

$$
I P I=\frac{1}{3} I R I+\frac{1}{3} I M I+\frac{1}{3} M P I
$$

Observed values of the IPI indicator are brought to a scale between 0 and 100 multiplying the IPI by a score of 10. The left-hand side indicator of Eq. (1) measures the innovation potential of each EU-funded research project and serves as dependent variable in the regression analyses of Sect. 5 .

\subsection{Organisational and geographic diversity}

To construct the focus explanatory variables which measure the organisational and geographic diversity in EU-funded collaborative research projects, IR survey data was complemented with information on projects' characteristics retrieved from the CORDIS database (Mankins 2009). This database is the European Commission's public repository of information on all EU-funded research projects and their results. For the purpose of this study, we retrieved, among others, information on the type and location of project participants, which allowed us to create measures of organisational and geographic diversity at project level. The organisational and geographic diversity measures are calculated as inverse Herfindahl indices. The Herfindahl index is among the most accepted measures of diversity in the economic literature (Patil and Taillie 1982; McDonald and Dimmick 2003). It has been widely used in the context of innovation and $R \& D$ collaborations to measure geographic (Beers and Zand 2014), organisational (Talke et al. 2011; Von Raesfeld et al. 2012) or technological diversity (Baum et al. 2000; Van de Vrande 2013). Organisational and geographic diversity—respectively denoted as $D_{p}^{O R G}$ and $D_{p}^{G E O}$ — are calculated as follows:

\footnotetext{
${ }^{2}$ Internal consistency of the different items into their respective aggregated sub-indicators rests upon theoretical groundings of the literature and correlation analyses among the various items in each sub-indicator. These analyses reveal significant positive correlations across the various items, indicating that each item uniquely contributes to the measurement in the construct they are intended to measure, i.e. market potential, innovation readiness and innovation management.
} 


$$
\mathrm{D}_{\mathrm{p}}^{O R G}=1-\sum_{o=1}^{O}\left(\mathrm{~s}_{o p}\right)^{2} \quad \text { and } \quad \mathrm{D}_{\mathrm{p}}^{G E O}=1-\sum_{c=1}^{C}\left(\mathrm{~s}_{c p}\right)^{2}
$$

Indices $D_{p}^{O R G}$ and $D_{p}^{G E O}$ sums the squared shares of respectively organisation type $o$ and country $c$ in FP project $p$ and deducts it from unity. Hence, the higher the values of $D_{p}^{O R G}$ and $D_{p}^{G E O}$, the more diverse the distributions of organisation types and countries in the research networks.

\subsection{Project characteristics}

We control for other types of characteristics that may affect the innovation potential of EUfunded research projects. First, we include the geographic distance between the different partners of the research consortium. Using geographical latitude and longitude information from the Geonames geographical database, we calculate - for each partner of the project the distances between its city and the cities of its co-partners with the great-circle distance method. The geographical distance in a research project is then defined as the average of all these distance measures.

Second, we include two dummy variables that control for the maturity of the project, denoted as interim review and final review. Each of them takes the value of 1 if the project is reviewed for the second or third time respectively and 0 otherwise. The reference group is the first review of a project. The maturity of the research project might influence its innovation potential in several ways. Time is a salient factor in developing a fertile ground for knowledge dissemination, assimilation and understanding within the project network (Schwartz et al. 2012). It requires frequent social interactions between the research partners, which are essentially based on trust and reciprocity (Dahl and Pedersen 2004; Niedergassel and Leker 2011). However, the development of trust and reciprocity takes considerable time and requires continuous efforts from all cooperating partners. Hence, as the duration of the cooperation advances, trust-based relationships between research partners strengthen, which further reduces freeriding or opportunistic behaviour and increases the project's probability of innovative success (Morgan and Cooke 1998).

Finally, we control for the amount of funding the project consortium received (project funding) and for the total duration of the project (project duration).

\section{Descriptive statistics}

Table 1 provides an overview of the sample of innovation projects and organisation types that we have investigated in the current study. Between October 2014 and January 2016, 603 EU-funded collaborative research projects were reviewed using the Innovation Radar questionnaire, including nearly $10 \%$ of all ICT FP7, CIP ICT PSP and Horizon2020 projects. As a result, 1128 innovations were identified. This means that, on average, every project produces nearly 2 innovations. The number of organisations active in these projects amounted to 7193. We distinguished six types of organisations, including universities, research centres, small -and medium-sized enterprises, large firms, governmental institutions and others. Universities account for almost one third of the organisations, while research centres and the two types of firms have respective shares around $20 \%$. The 
Table 1 Overview of innovation projects and organisation types

\begin{tabular}{ll}
\hline Review period & $10 / 2014$ and $01 / 2016$ \\
Number of reviewed projects & 603 \\
Number of innovations & 1128 \\
Number of organisations & 7193 \\
Universities & $30 \%$ \\
Research centers & $19 \%$ \\
Small- and medium sized enterprises & $21 \%$ \\
Large firms & $19 \%$ \\
Governmental institutions & $6 \%$ \\
Others & $5 \%$ \\
\hline
\end{tabular}

Data source based on the Innovation Radar by DG Connect (Pesole and Nepelski 2016) and Cordis

Table 2 Organisational and geographic dispersion at project level

\begin{tabular}{lcccc}
\hline Indicator (per project) & Mean & SD & Min. & Max. \\
\hline Number of organisations & 12.01 & 8.17 & 3 & 96 \\
Number of organisation types & 3.82 & 1.13 & 1 & 6 \\
Number of countries & 5.89 & 3.13 & 2 & 30 \\
\hline
\end{tabular}

Data source based on the Innovation Radar by DG Connect (Pesole and Nepelski 2016) and Cordis

percentage of both the governmental institutions and other types of organisations amounts to $6 \%$ and $5 \%$ respectively.

Further insights at the project level are presented in Table 2, highlighting the number of organisations, organisation types and represented countries per project. On average, every project involves twelve organisations and includes four different organisation types, active in six different countries. These descriptive statistics demonstrate the aim of EU-funded research frameworks to create institutionally and internationally diverse research networks. Most of the projects include three to four different organisation types (65\%), while the share of projects having five to six types amounts to $23 \%$. Only eleven projects report that they have one organisation type active in the innovation development (only involving universities). Concerning the geographical dispersion of research partners, projects include at least two different countries, and can include as many as 30 countries.

Table 3 presents summary statistics of the 603 EU-funded research projects. Research projects diverge widely in their innovation potential. The project with the highest score obtained 88.33 points, while the lowest-ranked project got only 14.08 points. Substantial differences can also be observed for organisational and geographic diversity measures. The table provides further details about project characteristics, including geographical distance across all research partners, project duration, project funding and the review stage. The correlation table between the variables is included in the Appendix. 
Table 3 Descriptive statistics of EU-funded research projects

\begin{tabular}{|c|c|c|c|c|c|}
\hline Variables & Obs & Mean & SD & Min & Max \\
\hline Innovation potential & 603 & 49.21 & 14.08 & 14.17 & 88.33 \\
\hline Organisational diversity & 603 & 0.62 & 0.14 & 0.00 & 0.79 \\
\hline Geographic diversity & 603 & 0.75 & 0.08 & 0.45 & 0.96 \\
\hline Geographical distance & 603 & 14.02 & 14.34 & 0.52 & 166.66 \\
\hline Final review & 603 & 0.42 & 0.49 & 0.00 & 1.00 \\
\hline Interim review & 603 & 0.34 & 0.48 & 0.00 & 1.00 \\
\hline Project funding & 603 & 3587.43 & 2734.38 & 228.00 & $41,000.00$ \\
\hline Project duration & 603 & 37.94 & 6.52 & 16.00 & 67.00 \\
\hline
\end{tabular}

Data source based on the Innovation Radar by DG Connect (Pesole and Nepelski 2016) and Cordis. Geographical distance, project funding and project duration are expressed respectively in thousand kilometres, thousand euros and months

\section{Empirical results}

We report the OLS estimations analysing the relationship between the organisational and geographic diversity in EU-funded research projects and their innovation potential in Table 4. The results reveal that organisational diversity in EU-funded research projects has a positive effect on their innovation potential. In other words, research projects with a greater heterogeneity of organisation partners have more innovation potential. In line with previous studies, these findings point to the advantages of organisational diversity that may arise through various means such as access to complementary assets (Teece 1986; Hagedoorn 1993), a wider range of capabilities and perspectives driven by a broader network of relationships, and the promotion of knowledge diffusion (Ahuja 2000; Das and Teng 2000), among others. Though innovative outcomes of organisational collaborations may be negatively affected by the variety of institutional cultures, problems of distrust or differences in objectives across organisations (Goerzen and Beamish 2005; Harryson et al. 2008; Pandza et al. 2011), the positive coefficient of the organisational diversity indicator suggests that the beneficial effects of a wider diversity of organisation types outweigh the negative impact of these challenges.

The innovation potential of EU-funded research projects is negatively affected by geographic diversity. This finding is consistent with the previous literature which points to the challenges arising from collaborations with internationally-diverse partners. Research projects with a wider heterogeneity of international partners may encounter increased costs of information transfer and face-to-face communications and difficulties due to language differences (De Meyer 1993; Welch and Welch 2008).

In column 2, we control for the geographical distance between the various organisations of the research consortia. Contrary to our expectations, the geographical distance between partners has a positive impact on the innovation potential of research projects (Audretsch and Feldman 1996; Asheim and Gertler 2005). This positive impact can be due to the fact that we do not control for partner-specific characteristics (Branstetter and Sakakibara 2002). As such, the geographical distance indicator may capture the beneficial effects of strong relational ties with more distant partners that possess the specialised knowledge needed for innovation development. In a similar context of strategic alliances, Capaldo and Petruzzelli (2014) and Petruzzelli (2011) suggest that high geographical distance between 
Table 4 Organisational and geographic diversity and innovation potential of EU-funded research projects

\begin{tabular}{lll}
\hline & Innovation potential & $0.068^{* * *}$ \\
\hline Organisational diversity & $0.075^{* * *}$ & $(0.020)$ \\
Geographic diversity & $(0.019)$ & $-0.326^{* *}$ \\
Geographical distance & $-0.199 *$ & $(0.135)$ \\
& $(0.109)$ & $0.038^{*}$ \\
Final review & & $(0.020)$ \\
Interim review & & $0.270^{* * *}$ \\
Project funding & $0.271 * * *$ & $(0.029)$ \\
Project duration & $(0.029)$ & $0.088^{* * *}$ \\
Constant & $0.088^{* * *}$ & $(0.032)$ \\
Observations & $(0.032)$ & $0.082^{* * *}$ \\
F-statistic & $0.092^{* * *}$ & $(0.026)$ \\
\hline
\end{tabular}

All models report OLS regression estimates. Robust standard errors are presented in parentheses

*Significant at $10 \%, * *$ significant at $5 \%, * * *$ significant at $1 \%$

partners can provide the alliance with the heterogeneous knowledge resources needed for successful innovation.

Both control variables - final review and interim review - which account for the maturity of the research project are positive and significant. As research projects in the first review serve as a reference group, these findings indicate that the innovation potential of research projects increases during the project. Concerning the remaining features of the research projects, the amount of funding has a positive impact on innovation potential while the project duration seems to negatively affect its innovative outcome. The positive effect of the amount of resources that is devoted to an FP project is in line with findings of Schwartz et al. (2012) that explored a sample of German subsidised R\&D cooperative projects.

As both the dependent variable and the variables of interest are expressed as logarithms, estimated coefficients can be interpreted as elasticities. A doubling of the degree of organisational diversity would increase the innovation potential of a project by 7.5 percent. In sharp contrast, a doubling of the degree of geographic diversity would lead to a nearly 20 percent decrease of a project's innovation potential. The negative impact of geographic diversity increases to roughly 30 percent after controlling for the geographical distance.

These results highlight the importance of the project design and in particular the relatively high negative impact of a large geographic diversity within the research consortium. Although results provide an indication of the magnitude and importance of the diversity impact, caution is required in interpreting the directionality of the effects. Given the crosssectional nature of the data, we cannot ascertain causality and should merely interpret results as associations. 


\section{Conclusions}

Considering that the publically-funded research programmes produce technologies that often form the basis for new products, services and markets, such instruments as the EC Framework Programme improve the framework and systemic conditions of entrepreneurial ecosystems. It accelerates the knowledge and technology production process and increases the stock of knowledge available to new technology-based firms. These firms are often the vehicles for the commercialisation of new knowledge and technologies. The key element of the EC FP is facilitating and exploiting the potential of diversified research networks.

The level of diversity of EC FP is quite considerable. For example, during the $7^{\text {th }}$ Framework Programme, 25.000 projects out of more than 139.000 research proposals received funding. Nearly 30.000 organisations participated to these projects. Universities and research organisations accounted for over $71 \%$ of all participating organisations. Private companies, including SMEs, represented the second largest group (Fresco et al. 2015). The Framework Programme by conception is a collaborative programme with global outreach open to all researchers and research organisations irrespective of their country of origin. FP7 has attained unprecedented levels of international participation by involving researchers in retained proposals from as many as 170 countries from all continents (EC 2015).

In this paper, we examined the impact of both organisational and geographic diversity on the commercial potential of innovations developed by research networks funded by EU Framework Programmes. An extensive body of literature has analysed the advantages and drawbacks of organisational diversity in collaborative research and explored the various challenges that can arise in collaborations with internationally-dispersed research partners. Not many studies have specifically assessed the effect of diversity in Framework Programmes. These studies were more descriptive in nature (Pandza et al. 2011) and often assessed the beneficial effects on firms' economic performance from engaging in these collaborative research projects (Bayona-Sáez and García-Marco 2010; Barajas et al. 2012; Aguiar and Gagnepain 2017). However, none of these studies investigated how the design of the research consortium in terms of organisational and geographic diversity related to the commercial potential of innovations of EU-funded collaborative research projects.

Using a sample of 603 EU-funded collaborative research projects with an ICT theme, this paper provides evidence of the importance of the composition of innovation partnerships in research collaborations. Our findings suggest that projects with a wider diversity in research partners are more likely to deliver innovations with a greater potential. This indicates that these projects reap the benefits of the various advantages associated with more organisational diversity such as greater learning opportunities, enhanced creativity and access to a broader network of knowledge sources and competences. Although wider organisational diversity generates difficulties in reconciling the different objectives and time-frames of the various types of research partners, the net effect of a more institutionally diverse research team seems to be positive.

In contrast, research networks with greater geographic diversity are associated with lower levels of innovation potential. This finding is in line with the literature which suggests that a larger heterogeneity of international partners in collaborative projects may increase the costs of information transfer and face-to-face communications (De Meyer 1993; Welch and Welch 2008). Contrary to our expectations, the geographical distance between partners has a positive impact on the innovation potential of research projects. This lets us assume that organisations choose their partners based on their specialised knowledge assets and that the geographic distance does not prevent them from engaging in collaboration. This conjecture can be confirmed once information on partner-specific scientific and technological capabilities is available. 
The construction of such a large research programme as the EC FP represents a major challenge. Our results show that besides such elements as the duration of funding of projects, the composition of the teams participating to them plays an equally important role. Just as there are decreasing returns to the number of participants (Breschi and Malerba 2011), there are limits to diversity of the participating organisations. Our results show, in particular, that the geographical mix poses a challenge and can create tensions within the project consortia, which can reduce their performance. Thus, such requirements as, for example, in the $\mathrm{H} 2020$ programme to create consortia of organisations including at least 3 participants from 3 different EU Member States or Associated countries may not necessarily increase the productivity of project consortia (EC 2018).

Our sample is restricted to the ICT theme of the FP. We have however to acknowledge that various scientific and technological domains exhibit specific dynamics and configurations (Bonaccorsi 2008). In particular, emerging and high-growth fields in science, such as computer science, biotechnology and life sciences, materials sciences and nanotechnology, are characterized by theme-specific degrees of diversity and of complementarities, both at the cognitive and institutional level, requiring active cooperation forms between different disciplines and actors. In order to achieve efficient productive settings, these theme-specific characteristics need to be taken into account while constructing heterogeneous collaborations.

In the context of the ICT or digital theme, one needs to consider the issue of participation of early-stage ventures in collaborative projects or the process of creation of such ventures with the objective of commercialisation of the research results. Young, technologybased enterprises, including start-ups and spin-offs, are the main vehicles through which new knowledge from science and engineering is converted into economic benefits (Acs et al. 2009a; b). These companies are more likely than others to pursue opportunities associated with radical innovations that produce positive knowledge externalities and may have transformative consequences for the entire society (Baumol et al. 2007). This is particularly true for ICT sector companies and digitally-enabled companies. By increasing the level of participation of early-stage ventures in FP projects, the EC could accelerate the knowledge and technology production and commercialisation process.

Our research was subject to a number of limitations, which may also suggest directions for future research. First, we lacked information about the level of technological relatedness across industry partners within research networks, which had been reported in prior studies as a relevant factor for the outcome of collaborations (Branstetter and Sakakibara 2002). A greater degree of technological proximity between firms could facilitate the exchange, the assimilation and the use of knowledge within the research consortium. If technological divergence between the partners is large, an industry partner's knowledge would be largely unexploitable for its counterparts. Hence, an interesting future research project would be to construct a technological proximity measure based on patent information of the industry partners. Second, linking industry partners to third-party databases would also allow us to control for the quality of firms active in the research project, including measures of firm size, value added and productivity growth. Information on the use of VC funding by organisations participating to the EU-funded research projects would improve our understanding of the position and role of publically-funded research programmes within the entrepreneurial ecosystems. It would cast light on the interplay between public and private sources of funding and the access to funding at each stage of technology development and commercialisation (Auerswald and Branscomb 2003). Third, the innovation potential of EU-funded research projects may also depend on the quality of other types of research partners. This calls for the inclusion of quality measures of universities, public research centres and governmental institutions in the estimation analyses. 
Open Access This article is distributed under the terms of the Creative Commons Attribution 4.0 International License (http://creativecommons.org/licenses/by/4.0/), which permits unrestricted use, distribution, and reproduction in any medium, provided you give appropriate credit to the original author(s) and the source, provide a link to the Creative Commons license, and indicate if changes were made.

\section{Appendix}

See Table 5 .

Table 5 Correlation table

\begin{tabular}{|c|c|c|c|c|c|c|c|c|c|}
\hline & Variables & (1) & (2) & (3) & (4) & (5) & (6) & (7) & (8) \\
\hline (1) & Innovation potential & 1.000 & & & & & & & \\
\hline (2) & Organisational diversity & 0.173 & 1.000 & & & & & & \\
\hline (3) & Geographic diversity & 0.007 & 0.153 & 1.000 & & & & & \\
\hline (4) & Geographical distance & 0.110 & 0.252 & 0.582 & 1.000 & & & & \\
\hline (5) & Final review & 0.337 & 0.038 & 0.053 & 0.027 & 1.000 & & & \\
\hline (6) & Interim review & -0.106 & 0.012 & -0.035 & 0.010 & -0.611 & 1.000 & & \\
\hline (7) & Project funding & 0.119 & 0.107 & 0.274 & 0.322 & -0.065 & 0.165 & 1.000 & \\
\hline (8) & Project duration & 0.021 & -0.052 & 0.106 & 0.106 & -0.016 & 0.163 & 0.570 & 1.000 \\
\hline
\end{tabular}

\section{References}

Acs, Z. J., Audretsch, D. B., \& Strom, R. J. (2009a). Entrepreneurship, growth, and public policy. Cambridge: Cambridge University Press.

Acs, Z. J., Braunerhjelm, P., Audretsch, D. B., \& Carlsson, B. (2009b). The knowledge spillover theory of entrepreneurship. Small Business Economics, 32(1), 15-30.

Aguiar, L., \& Gagnepain, P. (2017). European cooperative R\&D and firm performance: Evidence based on funding differences in key actions. International Journal of Industrial Organization, 53, 1-31.

Ahonen, P., \& Tienari, J. (2009). United in diversity? Disciplinary normalization in an EU project. Organization, 16(5), 655-679.

Ahuja, G. (2000). The duality of collaboration: inducements and opportunities in the formation of interfirm linkages. Strategic Management Journal, 21(3), 317-343.

Ahuja, G., \& Lampert, M. C. (2001). Entrepreneurship in the large corporation: a longitudinal study of how established firms create breakthrough inventions. Strategic Management Journal, 22(6-7), 521-543.

Anselin, L., Varga, A., \& Acs, Z. (1997). Local geographic spillovers between university research and high technology innovations. Journal of Urban Economics, 42(3), 422-448.

Archibugi, D., \& Coco, A. (2004). International partnerships for knowledge in business and academia: A comparison between Europe and the USA. Technovation, 24(7), 517-528.

Aristei, D., Vecchi, M., \& Venturini, F. (2016). University and inter-firm R\&D collaborations: propensity and intensity of cooperation in Europe. The Journal of Technology Transfer, 41(4), 841-871.

Arrow, K. (1962). Economic welfare and the allocation of resources for invention. In NBER (Ed.), The rate and direction of inventive activity: Economic and social factors (pp. 609-626). Princeton: Princeton University Press.

Asheim, B., \& Gertler, M. (2005). Regional innovation systems and the geographical foundations of innovation. In J. Fagerberg, D. Mowery, \& R. R. Nelson (Eds.), The Oxford handbook of innovation (pp. 291-317). Oxford: Oxford University Press.

Astebro, T. (2004). Key success factors for technological entrepreneurs R\&D projects. IEEE Transactions on Engineering Management, 51(3), 381-399.

Audretsch, D. B., \& Feldman, M. P. (1996). R\&D spillovers and the geography of innovation and production. The American Economic Review, 86(3), 630-640. 
Audretsch, D. B., \& Link, A. N. (2016). Essays in public sector entrepreneurship. Cham: Springer.

Auerswald, P., \& Branscomb, L. (2003). Valleys of death and Darwinian seas: financing the invention to innovation transition in the United States. The Journal of Technology Transfer, 28(3), 227-239.

Balachandra, R., \& Friar, J. H. (1997). Factors for success in R\&D projects and new product innovation: a contextual framework. IEEE Transactions on Engineering Management, 44(3), 276-287.

Barajas, A., Huergo, E., \& Moreno, L. (2012). Measuring the economic impact of research joint ventures supported by the EU framework programme. The Journal of Technology Transfer, 37(6), 917-942.

Baum, J. A. C., Calabrese, T., \& Silverman, B. S. (2000). Don't go it alone: alliance network composition and startups' performance in Canadian biotechnology. Strategic Management Journal, 21(3), 267-294.

Baumol, W. J., Litan, R. E., \& Schramm, C. J. (2007). Good capitalism, bad capitalism, and the economics of growth and prosperity. New Haven: Yale University Press.

Bayona-Sáez, C., \& García-Marco, T. (2010). Assessing the effectiveness of the Eureka program. Research Policy, 39(10), 1375-1386.

Beers, C., \& Zand, F. (2014). R\&D cooperation, partner diversity, and innovation performance: an empirical analysis. Journal of Product Innovation Management, 31(2), 292-312.

Belderbos, R., Carree, M., \& Lokshin, B. (2004). Cooperative R\&D and firm performance. Research Policy, 33(10), 1477-1492.

Bonaccorsi, A. (2008). Search regimes and the industrial dynamics of science. Minerva, 46(3), 285.

Boschma, R. (2005). Proximity and innovation: a critical assessment. Regional Studies, 39(1), 61-74.

Branstetter, L. G., \& Sakakibara, M. (2002). When do research consortia work well and why? Evidence from Japanese panel data. The American Economic Review, 92(1), 143-159.

Breschi, S., \& Malerba, F. (2011). Assessing the scientific and technological output of EU framework programmes: Evidence from the FP6 projects in the ICT field. Scientometrics, 88(1), 239-257.

Brett, J., Behfar, K., \& Kern, M. C. (2006). Managing multicultural teams. Harvard Business Review, 84(11), 84-91.

Caloghirou, Y., Ioannides, S., \& Vonortas, N. S. (2003). Research joint ventures. Journal of Economic Surveys, 17(4), 541-570.

Caloghirou, Y., Tsakanikas, A., \& Vonortas, N. (2001). University-Industry Cooperation in the context of the European framework programmes. The Journal of Technology Transfer, 26(1-2), 153-161.

Caloghirou, Y., Vonortas, N. S., \& Ioannides, S. (2004). European collaboration in research and development: Business strategy and public policy. Cheltenham: Edward Elgar Publishing.

Capaldo, A., \& Petruzzelli, A. M. (2014). Partner geographic and organizational proximity and the innovative performance of knowledge-creating alliances. European Management Review, 11(1), 63-84.

Carayol, N. (2003). Objectives, agreements and matching in science-industry collaborations: reassembling the pieces of the puzzle. Research Policy, 32(6), 887-908.

Coad, A., Amoroso, S., \& Grassano, N. (2017). Diversity in one dimension alongside greater similarity in others: evidence from FP7 cooperative research teams. The Journal of Technology Transfer, 42(5), 1170-1183.

Cohen, W. M., \& Levinthal, D. A. (1990). Absorptive capacity: A new perspective on learning and innovation. Administrative Science Quarterly, 35(1), 128-152.

Conceição, O., Fontes, M., \& Calapez, T. (2012). The commercialisation decisions of research-based spinoff: Targeting the market for technologies. Technovation, 32(1), 43-56.

Cooper, R. G., \& Kleinschmidt, E. J. (1988). Resource allocation in the new product process. Industrial Marketing Management, 17(3), 249-262.

Cooper, R. G., \& Kleinschmidt, E. J. (1997). Winning businesses in product development: The critical success factors. The Journal of Product Innovation Management, 14(2), 132.

Cox, T. (1993). Cultural diversity in organizations: Theory, research and practice. San Francisco, CA: Barrett-Koehler.

Cox, T. H., \& Blake, S. (1991). Managing cultural diversity: Implications for organizational competitiveness. The Executive, 5(3), 45-56.

Dahl, M. S., \& Pedersen, C. Ø. (2004). Knowledge flows through informal contacts in industrial clusters: Myth or reality? Research Policy, 33(10), 1673-1686.

Das, T. K., \& Teng, B.-S. (2000). A resource-based theory of strategic alliances. Journal of Management, 26(1), 31-61.

Davenport, S., Davies, J., \& Grimes, C. (1998). Collaborative research programmes: Building trust from difference. Technovation, 19(1), 31-40.

De Coster, R., \& Butler, C. (2005). Assessment of proposals for new technology ventures in the UK: Characteristics of university spin-off companies. Technovation, 25(5), 535-543. 
De Meyer, A. (1993). Management of an international network of industrial R\&D laboratories. $R \& D$ Management, 23(2), 109-120.

De Prato, G., Nepelski, D. \& Piroli, G. (2015). Innovation Radar: Identifying innovations and innovators with high potential in ICT FP7, CIP \& H2020 Projects, Joint Research Centre, science for policy report-EUR $27314 \mathrm{EN}$. https://doi.org/10.2791/61591.

Di Cagno, D., Fabrizi, A., \& Meliciani, V. (2014). The impact of participation in European joint research projects on knowledge creation and economic growth. The Journal of Technology Transfer, 39(6), $836-858$.

Doz, Y. L., \& Hamel, G. (1997). The use of alliances in implementing technology strategies. In M. L. Tushman \& P. Anderson (Eds.), Managing strategic innovation and change: A collection of readings (pp. 1-41). New York: Oxford University Press.

Duysters, G., \& Lokshin, B. (2011). Determinants of alliance portfolio complexity and its effect on innovative performance of companies. Journal of Product Innovation Management, 28(4), 570-585.

EC. (2014). Horizon 2020 Work Programme 2014-2015: Leadership in enabling and industrial technologies-information and communication technologies. Luxembourg: Office for Official Publications of the European Communities.

EC. (2015). Seventh FP7 monitoring report: Monitoring report 2013. Luxembourg: Publications Office of the European Union.

EC. (2016). Ex-Post Evaluation of the 7th EU framework programme (2007-2013). Luxembourg: Publications Office of the European Union.

EC. (2018). Participant Portal. H2020 Online Manual. http://ec.europa.eu/research/participants/docs/ h2020-funding-guide/index_en.htm. Accessed 20 Mar 2018.

Eisenhardt, K. M., \& Schoonhoven, C. B. (1996). Resource-based view of strategic alliance formation: Strategic and social effects in entrepreneurial firms. Organization Science, 7(2), 136-150.

Ely, R. J., \& Thomas, D. A. (2001). Cultural diversity at work: The effects of diversity perspectives on work group processes and outcomes. Administrative Science Quarterly, 46(2), 229-273.

Evanschitzky, H., Eisend, M., Calantone, R. J., \& Jiang, Y. (2012). Success factors of product innovation: An updated meta-analysis. Journal of Product Innovation Management, 29(S1), 21-37.

Faems, D., Van Looy, B., \& Debackere, K. (2005). Interorganizational collaboration and innovation: toward a portfolio approach. Journal of Product Innovation Management, 22(3), 238-250.

Freeman, C. (1991). Networks of innovators: A synthesis of research issues. Research Policy, 20(5), 499-514.

Fresco, L., Martinuzzi, A., Butkus, E., Cosnard, M., Hallen, A., Harayama, Y., Herlitschka, S., Kuhlmann, S., Nedeltcheva, V., Pelly, R., Anvret, M. \& Bustelo, M. (2015). Commitment and coherence. Ex-post-evaluation of the 7th EU framework programme (2007-2013).

Fuerlinger, G., Fandl, U., \& Funke, T. (2015). The role of the state in the entrepreneurship ecosystem: Insights from Germany. Triple Helix, 2-3(1), 1-26.

Galbraith, C. S., Ehrlich, S. B., \& DeNoble, A. F. (2006). Predicting technology success: Identifying key predictors and assessing expert evaluation for advanced technologies. The Journal of Technology Transfer, 31(6), 673-684.

Gampfer, R., Mitchell, J., Stamenov, B., Zifciakova, J. \& Jonkers, K. (2016). Improving access to finance: which schemes best support the emergence of high-growth innovative enterprises? A mapping, analysis and assessment of finance instruments in selected EU Member States, Joint Research Centre, science for policy report-EUR 28084 EN. https://doi.org/10.2791/635757.

Gerard, G., Shaker, Z., \& Robley, W. (2002). The effects of business-university alliances on innovative output and financial performance: A study of publicly traded biotechnology companies. Journal of Business Venturing, 17(6), 577-609.

Goerzen, A., \& Beamish, P. W. (2005). The effect of alliance network diversity on multinational enterprise performance. Strategic Management Journal, 26(4), 333-354.

Griffin, A. (1997). Modeling and measuring product development cycle time across industries. Journal of Engineering and Technology Management, 14(1), 1-24.

Gulati, R. (1999). Network location and learning: The influence of network resources and firm capabilities on alliance formation. Strategic Management Journal, 20(5), 397-420.

Hagedoorn, J. (1993). Understanding the rationale of strategic technology partnering: Nterorganizational modes of cooperation and sectoral differences. Strategic Management Journal, 14(5), 371-385.

Hagedoorn, J., \& Kranenburg, H. (2003). Growth patterns in R\&D partnerships: An exploratory statistical study. International Journal of Industrial Organization, 21(4), 517-531.

Hagedoorn, J., Link, A., \& Vonortas, N. (2000). Research partnerships. Research Policy, 29(4-5), 567-586.

Hansen, M. T. (1999). The search-transfer problem: The role of weak ties in sharing knowledge across organization subunits. Administrative Science Quarterly, 44(1), 82-111. 
Harryson, S., Kliknaite, S., \& Dudkowski, R. (2008). Flexibility in innovation through external learning: exploring two models for enhanced industry? University collaboration. International Journal of Technology Management, 41(1-2), 109-137.

Henard, D. H., \& Szymanski, D. M. (2001). Why some new products are more successful than others. Journal of Marketing Research, 38(3), 362-375.

Hennart, J.-F., \& Zeng, M. (2002). Cross-cultural differences and joint venture longevity. Journal of International Business Studies, 33(4), 699-716.

Hernán, R., Marín, P. L., \& Siotis, G. (2003). An empirical evaluation of the determinants of Research Joint Venture Formation. The Journal of Industrial Economics, 51(1), 75-89.

Heslop, L. A., McGregor, E., \& Griffith, M. (2001). Development of a technology readiness assessment measure: The cloverleaf model of technology transfer. The Journal of Technology Transfer, 26(4), 369-384.

Hoegl, M., \& Proserpio, L. (2004). Team member proximity and teamwork in innovative projects. Research Policy, 33(8), 1153-1165.

Jaffe, A. B., Trajtenberg, M., \& Henderson, R. (1993). Geographic localization of knowledge spillovers as evidenced by patent citations. The Quarterly Journal of Economics, 108(3), 577-598.

Keller, R. T. (1986). Predictors of the performance of project groups in R\&D organizations. Academy of Management Journal, 29(4), 715-726.

Kirchberger, M. A., \& Pohl, L. (2016). Technology commercialization: A literature review of success factors and antecedents across different contexts. The Journal of Technology Transfer, 41(5), 1077-1112.

Kogut, B. (1988). Joint ventures: Theoretical and empirical perspectives. Strategic Management Journal, 9(4), 319-332.

Laursen, K., \& Salter, A. (2006). Open for innovation: the role of openness in explaining innovation performance among UK manufacturing firms. Strategic Management Journal, 27(2), 131-150.

Lavie, D., \& Miller, S. R. (2008). Alliance portfolio internationalization and firm performance. Organization Science, 19(4), 623-646.

Lehmann, E. E., \& Menter, M. (2016). University-industry collaboration and regional wealth. The Journal of Technology Transfer, 41(6), 1284-1307.

Lerner, J., \& Merges, R. P. (1998). The control of technology alliances: An empirical analysis of the biotechnology industry. The Journal of Industrial Economics, 46(2), 125-156.

Leyden, D. (2016). Public-sector entrepreneurship and the creation of a sustainable innovative economy. Small Business Economics, 46(4), 553-564.

Liao, P., \& Witsil, A. (2008). A practical guide to opportunity assessment methods. New-York: Research Triangle Park, RTI Press.

Link, A. N. (2016). Public sector entrepreneurship: Introduction to the special section. Economia e Politica Industriale, 43(4), 355-356.

Linton, J. D., Walsh, S. T., \& Morabito, J. (2002). Analysis, ranking and selection of R\&D projects in a portfolio. R\&D Management, 32(2), 139-148.

Luukkonen, T. (1998). The difficulties in assessing the impact of EU framework programmes. Research Policy, 27(6), 599-610.

Luukkonen, T. (2000). Additionality of EU framework programmes1. Research Policy, 29(6), 711-724.

Mankins, J. (2009). Technology readiness assessments: A retrospective. Acta Astronautica, 65(9-10), $1216-1223$.

Mazzucato, M. (2013). The entrepreneurial state: debunking public vs. private sector myths. London: Anthem Press.

Mazzucato, M. (2016). From market fixing to market-creating: A new framework for innovation policy. Industry and Innovation, 23(2), 140-156.

McDonald, D. G., \& Dimmick, J. (2003). The conceptualization and measurement of diversity. Communication Research, 30(1), 60-79.

Meseri, O., \& Maital, S. (2001). A survey analysis of university-technology transfer in Israel: Evaluation of projects and determinants of success. The Journal of Technology Transfer, 26(1), 115-125.

Meyer-Krahmer, F., \& Reger, G. (1999). New perspectives on the innovation strategies of multinational enterprises: Lessons for technology policy in Europe. Research Policy, 28(7), 751-776.

Miles, G., Preece, S. B., \& Baetz, M. C. (1999). Dangers of dependence: The impact of strategic alliance use by small technology-based firms. Journal of Small Business Management, 37(2), 20.

Mitchell, W., \& Singh, K. (1996). Survival of businesses using collaborative relationships to commercialize complex goods. Strategic Management Journal, 17(3), 169-196.

Montoya-Weiss, M. M., \& Calantone, R. (1994). Determinants of new product performance: A review and meta-analysis. Journal of Product Innovation Management, 11(5), 397-417. 
Mora-Valentin, E. M., Montoro-Sanchez, A., \& Guerras-Martin, L. A. (2004). Determining factors in the success of R\&D cooperative agreements between firms and research organizations. Research Policy, $33(1), 17-40$.

Morgan, K., \& Cooke, P. (1998). The associational economy: Firms, regions, and innovation. New-York: Oxford University Press.

Nelson, R. R. (1959). The simple economics of basic scientific research. Journal of Political Economy, 67(3), 297-306.

Nepelski, D., \& Piroli, G. (2018). Organizational diversity and innovation potential of EU-funded research projects. Journal of Technology Transfer, 43(3), 615-639.

Nevens, M. (1990). Commercializing technology: What the best companies do. Planning Review, 18(6), 20-24.

Niedergassel, B., \& Leker, J. (2011). Different dimensions of knowledge in cooperative R\&D projects of university scientists. Technovation, 31(4), 142-150.

Oxley, J. E. (1997). Appropriability hazards and governance in strategic alliances: A transaction cost approach. Journal of Law Economics and Organization, 13(2), 387-409.

Pandza, K., Wilkins, T., \& Alfoldi, E. (2011). Collaborative diversity in a nanotechnology innovation system: Evidence from the EU framework programme. Technovation, 31(9), 476-489.

Patil, G., \& Taillie, C. (1982). Diversity as a concept and its measurement. Journal of the American Statistical Association, 77(379), 548-561.

Pavitt, K. (2005). Innovation processes. In J. Fagerberg, D. Mowery, \& R. Nelson (Eds.), The Oxford handbook of innovation (pp. 86-114). Oxford: Oxford University Press.

Pesole, A. \& Nepelski, D. (2016). Universities and collaborative innovation in EC-funded research projects: An analysis based on innovation radar data, Joint Research Centre, science for policy report-EUR 28355 EN. https://doi.org/10.2791/244949.

Petruzzelli, A. M. (2011). The impact of technological relatedness, prior ties, and geographical distance on university-industry collaborations: A joint-patent analysis. Technovation, 31(7), 309-319.

Pisano, G. P. (1990). The R\&D boundaries of the firm: an empirical analysis. Administrative Science Quarterly, 35(1), 153-176.

Polt, W., Vonortas, N., \& Fisher, R. (2008). The impact of publicly funded research on innovation: An analysis of European framework programmes for research and development. Brussels: European Commission.

Powell, W. W., \& Brantley, P. (1992). Competitive cooperation in biotechnology: Learning through networks. In N. Nohria \& R. Eccles (Eds.), Networks and organizations: Structure, form and action (pp. 366-394). Boston: Harvard Business School Press.

Powell, W. W., Koput, K. W., \& Smith-Doerr, L. (1996). Interorganizational collaboration and the locus of innovation: Networks of learning in biotechnology. Administrative Science Quarterly, 41(1), 116-145.

Protogerou, A., Caloghirou, Y., \& Siokas, E. (2013). Twenty-five years of science-industry collaboration: the emergence and evolution of policy-driven research networks across Europe. The Journal of Technology Transfer, 38(6), 873-895.

Röller, L.-H., Siebert, R., \& Tombak, M. (2007). Why firms form (or do not form) RJVs. The Economic Journal, 117(522), 1122-1144.

Rothwell, R. (1992). Successful industrial innovation: Critical factors for the 1990s. R\&D Management, 22(3), 221-240.

Schwartz, M., Peglow, F., Fritsch, M., \& Günther, J. (2012). What drives innovation output from subsidized R\&D cooperation?-Project-level evidence from Germany. Technovation, 32(6), 358-369.

Stahl, G. K., Maznevski, M. L., Voigt, A., \& Jonsen, K. (2010). Unraveling the effects of cultural diversity in teams: A meta-analysis of research on multicultural work groups. Journal of International Business Studies, 41(4), 690-709.

Stam, E. \& Spigel, B. (2016). Entrepreneurial ecosystems, Utrecht School of Economics. Discussion paper series nr: 16-13.

Talke, K., Salomo, S., \& Kock, A. (2011). Top management team diversity and strategic innovation orientation: The relationship and consequences for innovativeness and performance. Journal of Product Innovation Management, 28(6), 819-832.

Teece, D. J. (1986). Profiting from technological innovation: Implications for integration, collaboration, licensing and public policy. Research Policy, 15(6), 285-305.

Van de Vrande, V. (2013). Balancing your technology-sourcing portfolio: How sourcing mode diversity enhances innovative performance. Strategic Management Journal, 34(5), 610-621.

Van Roy, V. \& Nepelski, D. (2016). Assessment of framework conditions for the creation and growth of firms in Europe, Joint Research Centre, science for policy report-EUR 28167 EN. https://doi. org/10.2791/2811. 
Van Roy, V. \& Nepelski, D. (2017). Determinants of high-tech entrepreneurship in Europe, Joint Research Centre, science for policy report-EUR 28299 EN. https://doi.org/10.2791/96153.

Von Raesfeld, A., Geurts, P., Jansen, M., Boshuizen, J., \& Luttge, R. (2012). Influence of partner diversity on collaborative public R\&D project outcomes: A study of application and commercialization of nanotechnologies in the Netherlands. Technovation, 32(3), 227-233.

Welch, D. E., \& Welch, L. S. (2008). The importance of language in international knowledge transfer. Management International Review, 48(3), 339-360.

Zucker, L. G. (1986). Production of trust: Institutional sources of economic structure, 1840-1920. Research in Organizational Behavior, 8, 53-111. 